\title{
Pengaruh Lama Fermentasi Alami Pati Sagu terhadap Mutu Sensori Mi Basah dengan Substitusi Tepung Non Terigu (Mocaf, Tepung Ubi JalarKuning Terfermentasi, Tepung Kacang Hijau) (Effectts of Natural Fermentation Time of Sago Starch on Sensoric Quality of Wet Noodles Substituted with Non Wheat Flour (Mocaf, Fermented Yellow Sweet Potato Flour, Mung Bean Flour))
}

\author{
Mulizani', Yanti Meldasari Lubis', Normalina Arpi ${ }^{1 *}$ \\ ${ }^{1}$ Program Studi Teknologi Hasil Pertanian, Fakultas Pertanian, Universitas Syiah Kuala
}

\begin{abstract}
Abstrak. Pemanfaatan pangan lokal sagu dapat mengurangi konsumsi terigu dalam pembuatan mi. Tujuan penelitian ini untuk mempelajari pembuatan mi basah daripati sagu terfermentasi dan substitusi tepung (MOCAF, tepung ubi jalar fermentasi, dan tepung kacang hijau). Penelitian pembuatan mi basah menggunakan Rancangan Acak Kelompok (RAK) faktorial dengan 2 faktor. Faktor pertama, lama fermentasi pati sagu yang terdiri atas tiga taraf yaitu FI= 7 hari, F2=14 hari, dan F3= 21 hari. Faktor kedua adalah substitusi pati dengan tepung (80\%:20\%), dengan tiga taraf yaitu S1=pati sagu fermentasi : MOCAF, S2=pati sagu fermentasi:tepung ubi jalar kuning fermentasi, dan S3=pati sagu fermentasi:tepung kacang hijau. Analisis yang dilakukan adalah uji organoleptiksecara deskriptifuntukkelengketan, elastisitas, warna, aroma, dan overall mi basah.Pembuatan mi basah menunjukkan bahwa perlakuan lama fermentasi pati sagu F1 (7 hari) menghasilkan nilai elastisitas mi basah yang lebih tinggi (lebih baik) $(\mathrm{P} \leq 0,05)$, dibandingkan mi basah dari pati sagu F2 (14 hari) dan F3 (21 hari), walaupun kelengketan, dan aroma asam mi basahnya rendah (kurang baik) $(\mathrm{P} \leq 0,05)$. Produk mi basah terbaikyaitu mi yang terbuat dari pati sagu yang difermentasi 7 hari (F1) dengan substitusi tepung ubi jalar kuning terfermentasi dengan karakteristik kelengketan 2,05 (lengket), elastisitas 2,43 (tidak elastis), warna 2,30 (tidak cerah), aroma asam 2,80 (tidak asam), rasa asam 2,88 (tidak asam), dan overall 2,60 (baik).
\end{abstract}

Kata kunci: pati sagu, mi basah, mocaf, ubi jalar kuning, kacang hijau.

\begin{abstract}
Utilization of local food sago can reduce the consumption of wheat in the manufacture of noodles. The purpose of this research was to study the production of wet noodlesfromfermented sago starch and the use of flour substitution (mocaf, fermented sweet potato flour, and mung bean flour). A randomized block designwith 2 factors was used. First factorwas sago starch fermentation period consistingofthree levels (FI = 7 days, F2 = 14 days, and F3 = 21 days). Second factor was the substitution of sago starch with flour (80\%: 20\%) consisting of three levels $(\mathrm{S} 1$ = fermented sago starch: mocaf, $\mathrm{S} 2=$ fermented sago starch: fermented yellow sweet potato flour, and S3 = fermented sago starch: mung bean flour). Analysis of the products includeddescriptive organoleptic tests ofstickiness, elasticity, color, flavor, and overall of wet noodles. The results showed that sago starch fermentation time F1 (7 days) wasbetter $(\mathrm{P} \leq 0,05)$ than F2 and F3 in terms of elasticity of wet noodles, although the adhesiveness and the sour aroma of the wet noodles were low (worse) $(\mathrm{P} \leq 0,05)$. The best wet noodles was made from fermented sago starch (7 days; F1) with substitution of fermented yellow sweet potato flour which has the following characteristics: stickiness 2.05 (sticky), elasticity 2.43 (inelastic), color 2,30 (not bright), sourness aroma 2.80 (not sour), sourness taste 2.88 (not sour), and overalls 2.60 (good).
\end{abstract}

Keywords: sago starch, wet noodles, mocaf, yellow sweet potatoes, mung bean.

\section{PENDAHULUAN}

Mi adalah salah satu produk pangan yang populer di Indonesia. Bahan baku pembuatan mi pada umumnya mengunakan terigu. Terigu berasal dari gandum yang merupakan salah satu komoditas impor.Dengan meningkatnya konsumsi mi maka akan berpeluang semakin besarnya penurunan devisa negara dan akan terganggunya ketahanan pangan nasional. 
Salah satu alternatif untuk mengurangi penggunaan terigu adalah dengan memanfaatkan komoditas pangan lokal sebagai bahan pengganti terigu. Pangan lokal yang dapat digunakan diantaranya sagu, singkong, ubi jalar, dan kacang hijau. Namun mi yang terbuat dari komoditas pangan lokal ini masih memiliki banyak kelemahan dalam sifat fungsionalnya. Untuk itu perlu dilakukan modifikasi agar mi basah yang dihasilkan memiliki sifat fungsional yang lebih baik dan bisa diterima oleh konsumen.

Menurut Direktorat Gizi Departemen Kesehatan RI (1990), kandungan kalori pati sagu sebesar $353 \mathrm{kkal}$ tidak jauh berbeda dengan kalori dari terigu yaitu $340 \mathrm{kkal}$. Namun, protein yang terkandung dalam pati sagu sangat sedikit. Pada pati sagu tidak ada kandungan protein gliadin dan glutenin yang dapat membentuk lembaran yang memiliki tekstur elastis seperti pada adonan mi berbahan dasar terigu. Hasil penelitian tentang pemanfaatan sagu dalam proses pembuatan mi menunjukkan perlu adanya perlakuan tertentu untuk meningkatkan kualitas mi non terigu. Salah satu perlakuan yang dilakukan adalah metode modifikasi pati dengan cara fermentasi. Fermentasi alami pati sagu dan perlakuan kombinasi pati sagu dengan tepung lain diharapkan dapat memperbaiki struktur atau karakteristik dari mi.

Penelitian Yusmarini dkk. (2013) menunjukkan bahwa mi instan yang terbuat dari $100 \%$ pati sagu, belum memenuhi syarat mutu, karena tingkat keutuhan (tidak patah) dari mi yang dihasilkan hanya $82,46 \%$. Tussa'diah (2015) menyatakan fermentasi pati sagu menurunkan nilai $\mathrm{pH}$ pati sagu, dan cenderung meningkatkan nilai viskositas dingin pati, selain itu semakin lama $(15,20$, dan 25 hari) fermentasi alami sagu menyebabkan semakin menurunnya nilai cooking loss. Struktur mi basah dari hasil fermentasi alami lebih kuat dibandingkan mi basah dengan fermentasi menggunakan inokulum. Efendi (2010) menunjukkan semakin lama proses fermentasi singkong untuk menjadi MOCAF (Modified Cassava Flour) menyebabkan warna (derajat putih), viskositas, dan daya serap air semakin meningkat, akan tetapi terjadi penurunan terhadap bulk density. Arpi dkk. (2015) menyatakan fermentasi alami ubi kayu selama 7 hari dengan ketebalan potongan ubi $3 \mathrm{~cm}$ menghasilkan tepung ubi kayu terfermentasi yang sesuai untuk mi basah. Penelitian Alfiani (2015) menunjukkan bahwa hasil terbaik diperoleh dengan metode fermentasi ubi jalar kuning secara alami dengan lama perendaman 4 hari dan ketebalan 0,5 cm. Yuliani dkk. (2015) menyatakan substitusi sagu dengan tepung kacang hijau 4,7\% pada mi sagu kering dapat menurunkan nilai kekerasan, kelengketan, dan elongasi namun meningkatkan cooking loss. Diniyati (2012) menyatakan mi instan terigu yang disubstitusi ubi jalar merah $20 \%$ dan tepung kacang hijau $10 \%$ menyebabkan penurunan nilai tekstur, kekerasan, selain itu warna dan aroma mi memiliki tingkat kesukaan tertinggi dari panelis, tetapi tidak berpengaruh terhadap rasa mi.

Oleh karena itu, penelitian ini mempelajari pengaruh lama fermentasi pati sagu dan substitusi tepung (MOCAF, tepung ubi jalar fermentasi dan tepung kacang hijau) terhadap mutu sensori mi basah.

\section{METODE PENELITIAN}

Penelitian ini dilaksanakan pada bulan Juni-Oktober 2016. Penelitian ini dilaksanakan di Laboratorium Rekayasa Proses Pangan dan Industri, Laboratorium Analisis Pangan Hasil Pertanian, dan Laboratorium Uji Sensori Jurusan Teknologi Hasil Pertanian Fakultas Pertanian Unsyiah, Universitas Syiah Kuala, Darussalam, Banda Aceh.

\section{Bahan dan Alat}

Bahan yang digunakan dalam penelitian ini adalah pati sagu (Metroxylon sp.) merk Saba Sagu sebagai bahan utama yang berasal dari Aceh Singkil, MOCAF komersial merk 
daun singkong siap pakai dari Bandung, kacang hijau tanpa kulit yang dijadikan tepung dari pasar Peunayong Banda Aceh, ubi jalar kuning pasar Tungkop Banda Aceh, soda abu merk gajah, garam merk dolpin dan air. Alat-alat yang digunakan selama proses pengolahan meliputi wadah plastik, alat pengilingan mi (ampia), kompor, panci, sendok.

\section{Rancangan Penelitian}

Rancangan yang digunakan dalam analisis pati sagu fermentasi dan tepung non terigu adalah Rancangan Acak lengkap (RAL) sedangkan rancangan yang digunakan dalam pembuatan mi basah adalah Rancangan Acak Kelompok (RAK) faktorial dengan dua faktor. Faktor pertama yaitu lama fermentasi pati sagu dengan taraf $F 1=7$ hari, $F 2=17$ hari dan $F 3=21$ hari. Faktor kedua yaitu substitusi pati dan tepung (80\%:20\%) dengan taraf S1= pati sagu fermentasi : MOCAF, S2= pati sagu fermentasi : tepung ubi jalar kuning fermentasi dan S3= pati sagu fermentasi : tepung kacang hijau. Kombinasi perlakuan (p) yaitu: $3 \times 3=9$. Untuk memperoleh ketelitian dilakukan sebanyak 2 ulangan maka diperoleh 18 unit satuan percobaan.

\section{Analisis Data}

Untuk menguji pengaruh dari setiap faktor dan interaksi antar faktor terhadap parameter analisis, dilakukan analisis statistik dengan menggunakan ANOVA (Analysis of varians). Apabila perlakuan yang diberikan menunjukkan pengaruh terhadap parameter yang diuji, maka dilakukan uji lanjut BNT (Beda Nyata Terkecil).

\section{Proses Fermentasi Alami Pati Sagu (Tussa'diah, 2015)}

Pati sagu ditimbang masing-masing perlakuan sebanyak 350 g. Sagu yang sudah ditimbang dimasukkan ke dalam stoples untuk dilakukan proses fermentasi dengan cara merendam sagu yang telah ditambahkan air sebanyak $700 \mathrm{ml}$. Stoples diberi label, stoples pertama 7 hari, stoples kedua 17 hari dan stoples ketiga 21 hari. Fermentasi ini diulang sebanyak dua kali ulangan. Stoples kemudian ditutup mengunakan kain saring dan diletakkan pada suhu ruang dengan lama fermentasi atau penyimpanan seperti hari yang tertera pada label tiap stoples. Fermentasi sagu diaduk pada hari ke-3 fermentasi dan kelipatanya. Air rendaman dibuang setelah proses fermentasi. Sagu kemudian dicuci dengan air bersih dengan cara merendam pati sagu dalam $200 \mathrm{ml}$ air lalu diaduk secara merata. Setelah diaduk, pati sagu diendapkan sampai terpisah dari air(lama pengendapan 30 menit). Proses pencucian ini dilakukan sebanyak 3 kali. Pati sagu kemudian dijemur di bawah sinar matahari selama 18 jam jika matahari terik atau 27 jam jika kondisi hari mendung. Pati sagu yang telah kering dihaluskan dengan blender dan diayak menggunakan saringan dengan ukuran 80 mesh. Pati sagu disimpan dalam plastik bening dan dimasukkan kedalam stoples tertutup. Pati siap diaplikasikan sebagai bahan baku pembuatan mi.

\section{Proses Pembuatan Tepung Ubi Jalar Terfermentasi (Alfiani, 2015)}

Ubi jalar ditimbang sebanyak 1,5 kg, kemudian dikupas kulitnya.Ubi jalar yang sudah dikupas kemudian dipotong dengan ketebalan $0,5 \mathrm{~cm}$.Kemudian direndam dalam wadah yang berisi air sebanyak $1500 \mathrm{ml}$ dan ditutup dengan kain saring.Ubi jalar difermentasi selama 4 hari. Setelah difermentasi air hasil fermentasi dibuang dan ubi jalar dicuci, kemudian ditiriskan.Ubi jalar dikeringkan dengan sinar matahari hingga kering. Setelah kering ubi jalar dihaluskan menggunakan blender dan diayak dengan ayakkan 80 mesh. Lalu disimpan dalam plastik dan dimasukkan dalam stoples tertutup. Pati ubi jalar terfermentasi siap diaplikasikan.

$\overline{\text { Pengaruh Lama Fermentasi Alami Pati Sagu terhadap Karakteristik Pati dan Mutu Mi Basah dengan Substitusi }}$ Tepung Non Terigu (Mocaf, Tepung Ubi Jalar Kuning Terfermentasi, dan Tepung Kacang Hijau) 
Tahapan Aplikasi Pati Sagu dan Tepung dalam Pembuatan Mi (Tussa'diah, 2015)

Pati sagu yang sudah fermentasi ditimbang sebanyak $80 \mathrm{~g}$, dan tepung substitusi sebanyak 20 g. Perbandingan pati dan tepung substitusi yaitu 80\%:20\%.Pati sagu kemudian diambil sebanyak 20\% (16 g) untuk dijadikan gel. Setelah terbentuk gel, pati sagu dan tepung sisa yang sudah ditambahkan garam $2 \mathrm{~g}$ dan soda abu $1 \mathrm{ml}$ diaduk bersama gel dengan menggunakan tangan. Lama pengadukan antara 15-20 menit. Adonan diistrirahatkan selama 15 menit dalam keadaan dibungkus dengan plastik.Adonan dibentuk menjadi lembaran menggunakan ampia. Pembentukkan lembaran merupakan proses yang dilakukan untuk menghaluskan serat-serat pada adonan dan membentuk adonan menjadi lembaran. Kemudian adonan ditaburi tapioka secukupnya, kira-kira untaian-untaian mi tidak lengket satu sama lain pada saat dipotong menjadi untaian mi dengan menggunakan ampia dengan ketebalan 1,5 $\mathrm{mm}$. Lembaran dipotong menjadi untaian benang-benang mi selanjutnya dilakukan perebusan mi dalam air mendidih selama 2 menit. Mi yang telah direbus diangkat dan didinginkan dengan air yang mengalir, selanjutnya dilumuri dengan minyak makan sebanyak 1 sendok makan dan mi siap untuk dianalisis.

\section{Kelengketan Antar Mi}

\section{HASIL DAN PEMBAHASAN}

Hasil uji deskriptif kelengketan antar mi berkisar antara 1,53-2,20 dengan rata-rata 1,96 (lengket). Hasil sidik ragam kelengket antar mi menunjukkan bahwa perlakuaan berpengaruh nyata $(\mathrm{P} \leq 0,05)$ terhadap nilai uji kelengketan antar mi basah. Gambar 1 menunjukkan nilai uji deskriptif kelengketan antar mi cenderung baik yaitu pada perlakuan dengan lama fermentasi pati sagu selama 21 hari yang berbeda tidak nyata dengan pati sagu fermentasi 14 hari. Kelengketan antar mi ini diduga dipengaruhi karena berkurangnya kandungan amilosa yang keluar dari granula pati sehingga kandungan amilopektinnya yang berperan dalam pembentukan tekstur mi yang lebih lengket.

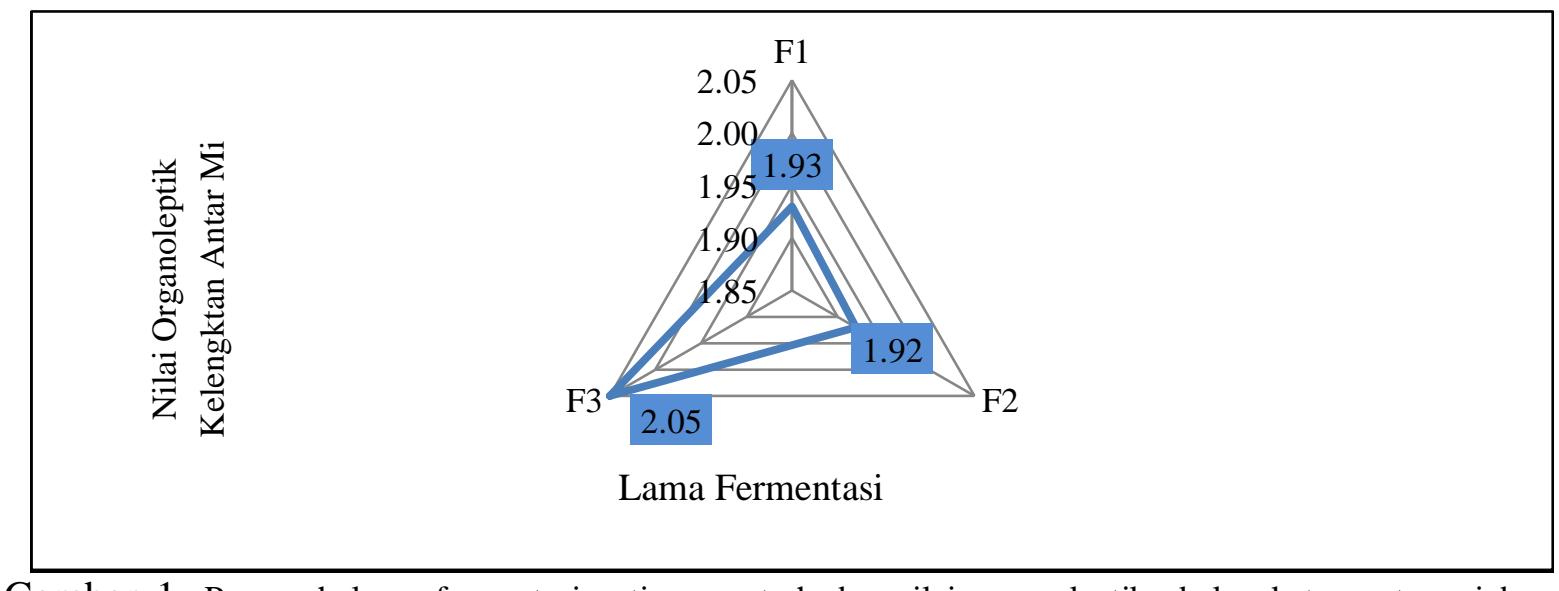

Gambar 1. Pengaruh lama fermentasi pati sagu terhadap nilai organoleptik kelengketan antar mi basah $\left(\mathrm{BNT}_{0,05}=0,14, \mathrm{KK}=9,05 \%\right.$. Nilai yang diikuti oleh huruf yang sama menunjukkan perbedaan yang tidak nyata). F0= pati sagu control, F1=fermentasi selama 7 hari, F2=fermentasi selama 14 hari, F3=fermentasi selama 21 hari. Nilai 1=sangat lengket, $2=$ lengket, dan 3=tidak lengket

Nilai uji deskriptif kelengketan antar mi cenderung baik yaitu pada perlakuan dengan lama fermentasi pati sagu selama 21 hari yang berbeda tidak nyata dengan pati sagu fermentasi 14 hari. Kelengketan antar mi ini diduga dipengaruhi karena berkurangnya kandungan amilosa yang keluar dari granula pati sehingga kandungan amilopektinnya yang

Pengaruh Lama Fermentasi Alami Pati Sagu terhadap Karakteristik Pati dan Mutu Mi Basah dengan Substitusi Tepung Non Terigu (Mocaf, Tepung Ubi Jalar Kuning Terfermentasi, dan Tepung Kacang Hijau)

(Mulizani, Yanti Melda Sari Lubis, Normalina Arpi)

Jurnal Ilmiah Mahasiswa Pertanian Unsyiah, Vol.2, No. 4, November 2017: 460-466 
berperan dalam pembentukan tekstur mi yang lebih lengket. Menurut Winarno (2002), semakin tinggi kandungan amilopektin maka akan semakin lengket. Amilopektin memiliki sifat lebih lengket dibandingkan amilosa.

\section{Elastisitas Mi Basah}

Uji organoleptik deskriptif elastisitas mi basah berkisar antara 2,05-2,42 dengan nilai rata-rata 2,27 (tidak elastis). Hasil sidik ragam elastisitas menunjukkan bahwa perlakuan lama fermentasi berpengaruh nyata $(\mathrm{P} \leq 0,05)$ terhadap nilai elastisitas mi basah. Gambar 2 menunjukkan adanya perbedaan pada perlakuaan fermentasi 7 hari.

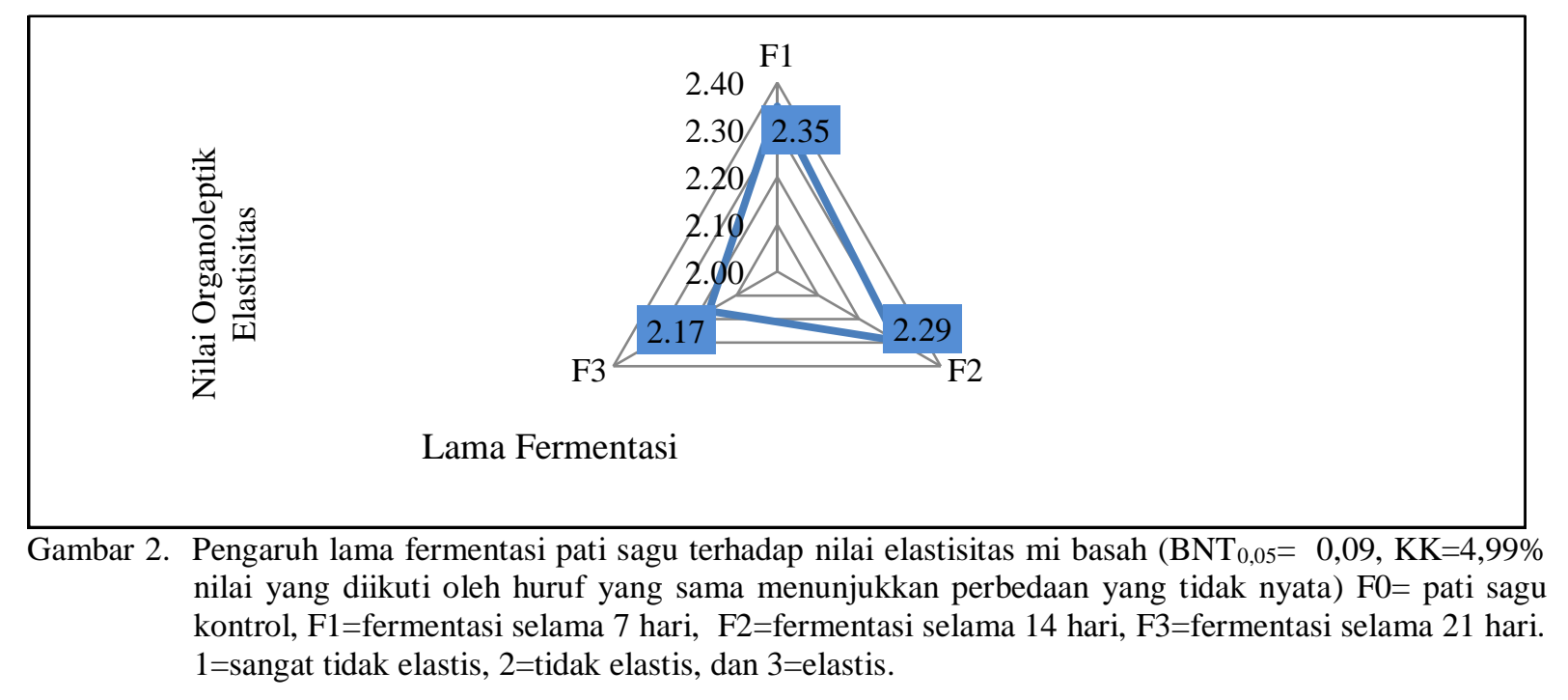

Semakin lama proses fermentasi maka akan semakin menurunnya nilai elastisitas dari mi basah yang dihasilkan. Menurut Anggreani dkk. (2014), selama fermentasi terjadinya proses degradasi terhadap komponen pati sehingga amilosa dan amilopektin secara fisik hanya dipertahankan oleh ikatan hidrogen yang kurang kokoh.

\section{Aroma Asam}

Hasil analisis uji deskriptif aroma asam mi basah berkisar antara 2,60-2,93 (tidak asam) dengan nilai rata-rata 2,79 (tidak asam). Hasil sidik ragam menunjukkan bahwa perlakuaan berpengaruh nyata $(\mathrm{P} \leq 0,05)$ terhadap nilai uji deskriptif aroma asam mi basah. Sedangkan substitusi tepung berpengaruh sangat nyata $(\mathrm{P} \leq 0,01)$ terhadap nilai uji deskriptif aroma asam mi basah. Gambar 3 menunjukkan nilai deskriptif aroma asam berbeda dari tiap perlakuan.Nilai deskriptif aroma asam berbeda dari tiap perlakuan, dimana panelis lebih menerima mi dengan lama fermentasi pati sagu selama 21 hari (F3). Hal ini diduga dengan semakin lama fermentasi bau khas dari pati sagu berkurang (hilang).

Gambar 4 menunjukkan parameter aroma asam yang dihasilkan dari mi basah pati sagu fermentasi dan substitusi tepung kacang hijau cenderung asam dibandingkan dengan MOCAF dan tepung ubi jalar fermentasi.Parameter aroma asam yang dihasilkan dari mi basah pati sagu fermentasi dan substitusi tepung kacang hijau cenderung asam dibandingkan dengan MOCAF dan tepung ubi jalar fermentasi. Tepung kacang hijau memiliki bau yang langau sehingga bau langu ini yang diasumsikan oleh para panelis sebagai aroma asam. Menurut Waiser (2003) bau langu disebabkan oleh aktivitas enzim lipoksigenase akan menyerang

Pengaruh Lama Fermentasi Alami Pati Sagu terhadap Karakteristik Pati dan Mutu Mi Basah dengan Substitusi Tepung Non Terigu (Mocaf, Tepung Ubi Jalar Kuning Terfermentasi, dan Tepung Kacang Hijau) 
rantai asam tak jenuh dan menghasilkan sejumlah senyawa yang lebih kecil bobot molekulnya, terutama senyawa aldehid dan keton.

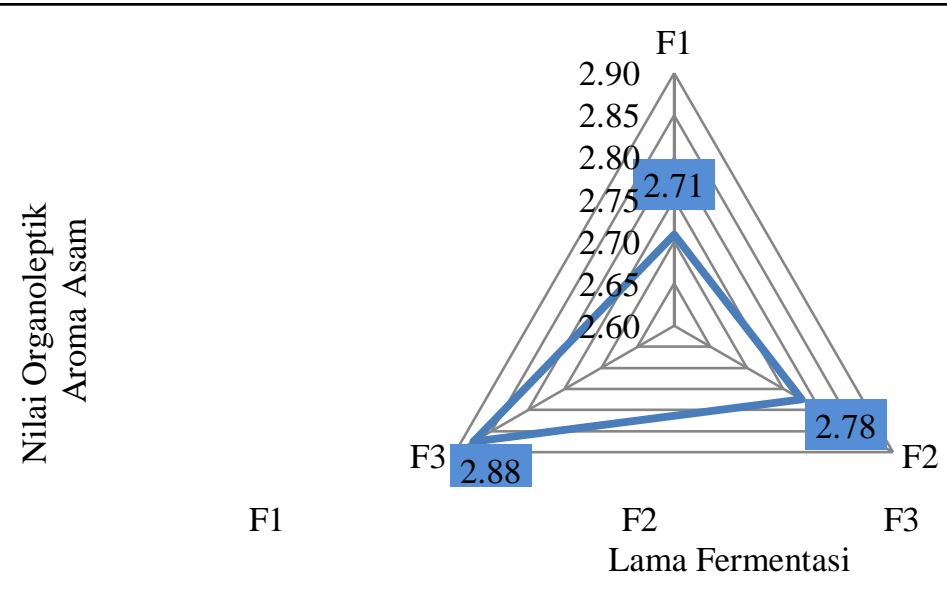

Gambar 3. Pengaruh lama fermentasi pati sagu terhadap nilai organoleptik aroma asam mi basah $\left(\mathrm{BNT}_{0,05}=0,05, \mathrm{KK}=2,27 \%\right.$ nilai yang diikuti oleh huruf yang sama menunjukkan perbedaan yang tidak nyata). $\mathrm{F} 0=$ pati sagu control, $\mathrm{F} 1=$ fermentasi selama 7 hari, F2= fermentasi selama 14 hari, F3=fermentasi selama 21 hari. Nilai 1=Sangat Asam, 2=Asam, dan 3=Tidak Asam.

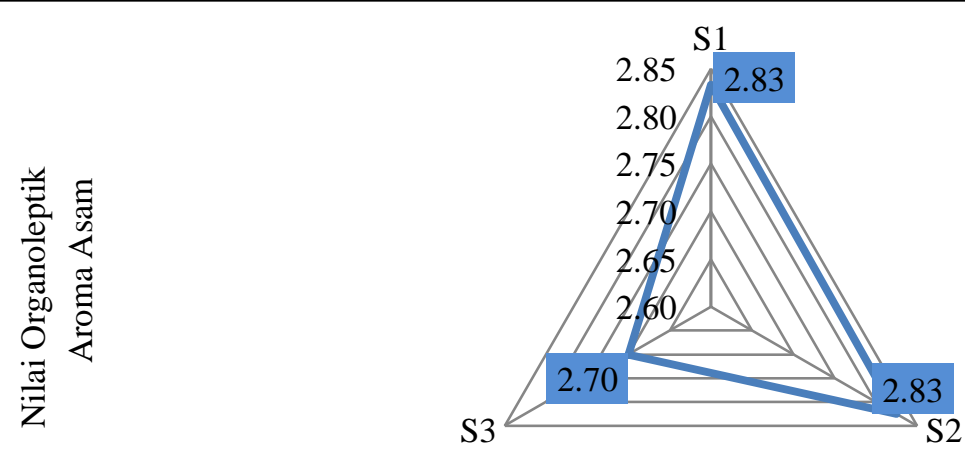

Tepung Substitusi

Gambar 4. Pengaruh tepung substitusi terhadap nilai organoleptik aroma asam mi basah $\left(\mathrm{BNT}_{0,05}=0,05, \mathrm{KK}=\right.$ $2,27 \%$ nilai yang diikuti oleh huruf yang sama menunjukkan perbedaan yang tidak nyata). S1=MOCAF, S2=Tepung Ubi Jalar Fermentasi, S3= Tepung Kacang Hijau. Nilai 1=Sangat Asam, 2=Asam, dan 3=Tidak Asam.

\section{KESIMPULAN DAN SARAN}

Mi basah yang terbaik diperoleh pada lama fermentasi pati sagu 7 haridengan substitusitepung ubi jalar kuning terfermentasi (F1S2) dengan nilai organoleptik kelengketan 2,05 ( lengket), elastisitas 2,43 (tidak elastis), warna 2,30(tidak cerah) aroma asam 2,80 (tidak asam), rasa asam 2,88 (tidak asam), overall 2,60 (baik).Perlu dilakukan penelitian lanjutan mengenai metode pemasakan mi dengan cara pengukusan agar dapat memperbaiki nilai organoleptik kelengketan antar mi. Selain itu perlu adanya penambahan pewarna agar misagu yang dihasilkan lebih menarik serta dilanjutkan untuk menjadi mi sagu kering atau mi sagu instan. 


\section{DAFTAR PUSTAKA}

Alfiani D. 2015. Pembuatan Mie Basah Dari Tepung Ubi Jalar Kuning termodifikasi Sebagai Subsitusi Terigu. [Skripsi]. Teknologi Hasil Pertanian. Unsyiah, Aceh.

Anggraeni, Y.P. dan S.S. Yuwono. 2014. Pengaruh Fermentasi Alami Pada Chips Ubi Jalar (Ipomoea batatas) Terhadap Sifat Fisik Tepung Ubi Jalar Terfermentasi. Jurnal Pangan dan Agroindustri 2(2):59-69.

Arpi N., A. Patria, N.E. Husna dan M. Novita. 2015. Pemafaatan Pangan Lokal Ubi Kayu Termodifikasi Secara Fermentasi Untuk Substitusi Terigu dalam Pembuatan Mie Basah. Prosinding Seminar Nasional Hasil Riset dan Standarisasi Industri V. Kementrian Perindustrian RI Badan Penelitian dan Pengembangan Industri Balai Riset dan Standarisasi Industri. Banda Aceh.

Diniyati, B. 2012. Kadar Betakaroten, Protein, Tingkat, Kekerasan Dan Mutu Organoleptik Mie Instan Dengan Substitusi Ubi Jalar Merah (Ipomoea batatas) Dan Kacang Hijau (Vigna radiata). [Skripsi]. Fakultas Kedokteran. Universitas Diponegoro, Semarang.

Efendi, P.J. 2010. Kajian Karakteristik Fisik Mocaf (Modified Cassava Flour) dari Ubi Kayu (Manihot esculenta Crantz) Varietas Malang-I Dan Varietas Mentega Dengan Perlakuan Lama Fermentasi [Skripsi]. Jurusan Teknologi Hasil Pertanian, Universitas Sebelas Maret, Surakarta.

Tussa'diah, H. 2015. Modifikasi Pati Sagu dengan Fermentasi Alami dan Baktri Asam Laktat (Lactobacillus plantarum) serta Aplikasinya Pada Pembuatan Mie Basah. [Skripsi]. Teknologi Hasil Pertanian. Unsyiah, Aceh.

Wieser, H. 2003. Determinasion of Gliadin and Gluten In Wheat Starch by Means of Alcohol Extraction and Gel Permeation Chromatography. Dalam Pratama, I.A. dan F.C. Nisa. 2014. Formulasi Mie Kering dengan Subsitusi Tepung Kimpul (Xanthosoma sagittifolium) dan Penambahan Tepung Kacang Hijau (Phaseolus radiatus L.). Jurnal Pangan dan Agroindustri (2)4:101-112.

Winarno, F.G. 2002. Kimia Pangan dan Gizi. PT. Gramedia Utama, Jakarta.

Yuliani, H., N.D. Yuliana, dan S. Budijanto. 2015. Fomulasi Mi Kering Sagu Dengan Subsitusi Tepung Kacang Hijau. Fakultas Teknologi Pertanian. ITB, Bogor. Jurnal Agritech, 35(4):387-395.

Yusmarini, U. Pato, S. Anirwan, dan H. Siregar. 2013. Mie Instan Berbasis Pati Sagu dan Ikan Patin Serta Pendugaan Umur Simpan dengan Metode Akserasi. Jurnal Teknologi dan Industri Indonesia 5 (2):25-33.

Pengaruh Lama Fermentasi Alami Pati Sagu terhadap Karakteristik Pati dan Mutu Mi Basah dengan Substitusi Tepung Non Terigu (Mocaf, Tepung Ubi Jalar Kuning Terfermentasi, dan Tepung Kacang Hijau)

(Mulizani, Yanti Melda Sari Lubis, Normalina Arpi)

Jurnal Ilmiah Mahasiswa Pertanian Unsyiah, Vol.2, No. 4, November 2017: 460-466 